\title{
EFEKTIVITAS TERAPI DUKUNGAN KELOMPOK DALAM MENINGKATKAN RESILIENSI PADA REMAJA PENGHUNI LEMBAGA PEMASYARAKATAN
}

\section{THE EFFECTIVENESS OF SUPPORT GROUP THERAPY TO IMPROVING RESILIENCE AMONG ADOLESCENTS IN PRISONS}

\author{
Rizky Harier Muiz \\ Rr. Indahria Sulistyarini \\ Fakultas Psikologi dan IImu Sosial Budaya Universitas Islam Indonesia Yogyakarta \\ Email: muizkhariry19@gmail.com
}

\begin{abstract}
This study aims to determine the effectiveness of support group therapy on improving resilience among adolescents in prisons. The hypothesis tested was based on the asumption that support group therapy influenced to improving resilience of adolescents in prison. The sample include 12 convicts adolescents, consist of male, they were between 16 and 18 years old, and classified into two groups, the two groups are experiment and control group. Data were collected by resilience scale (38-aitem) which refers to resilient aspects from Connor and Davidson (2003). The effectiveness of intervention was evaluated by using a quasi-experimental design with pretest-posttes and follow-up analysis. Analysis of this study consisted of quantitative and qualitative analysis. Quantitative analysis using parametric analysis of Anova Repeated Measures to determine differences in resilience to experimental group and control group after the subjects are given therapy. The qualitative analysis was done based on observations and interviews. The result of research showed there were differences in resilience between experimental group and control group after the therapy given, with value of $p=0.019(p<0.05)$ when pretest-posttest and $p=0.013(p<0.05)$ when pretest-follow up. The conclusion of this study was support group therapy can enhance resilience of adolescents in prisons.
\end{abstract}

Key words: Support group therapy, Resilience, Adolescents.

\section{INTISARI}

Penelitian ini bertujuan untuk mengetahui efektivitas terapi dukungan kelompok dalam meningkatkan resiliensi pada remaja di dalam lembaga pemasyarakatan. Subjek dalam penelitian ini adalah 12 narapidana remaja berjenis kelamin laki-laki dengan usia antara 16-18 tahun, dan terbagi menjadi dua kelompok, yaitu kelompok eksperimen dan kelompok kontrol. Penelitian ini menggunakan skala resiliensi (38 aitem) yang mengacu pada aspek-aspek resiliensi menurut Connor dan Davidson (2003). Analisis data dari penelitian ini terdiri dari analisis kuantitatif dan analisis kualitatif. Analisis data kuantitatif menggunakan teknik analisis parametrik Anava Campuran untuk melihat perbedaan resiliensi kelompok eksperimen dan kelompok kontrol setelah subjek diberikan terapi. Analisis kualitatif dilakukan berdasarkan hasil observasi dan wawancara. Hasilnya menunjukkan bahwa ada perbedaan resiliensi antara kelompok eksperimen dan kelompok kontrol setelah terapi diberikan, dengan nilai $p=0.019(p<0.05)$ pada saat prates-pascates dan $\mathrm{p}=0.013(\mathrm{p}<0.05)$ pada saat prates-tindak lanjut. Kesimpulan dari penelitian ini bahwa terapi dukungan kelompok dapat meningkatkan resiliensi remaja di dalam Lembaga Pemasyarakatan.

Kata Kunci: Terapi Dukungan Kelompok, Resiliensi 
Lembaga Pemasyarakatan Anak pada mulanya didirikan dengan tujuan melaksanakan pelayanan dan perawatan tahanan, pembinaan dan bimbingan Warga Binaan Pemasyarakatan (narapidana). Narapidana ditempatkan sebagai subjek dalam menangani permasalahan tentang anak, dan merupakan wadah sebagai media publikasi mengenai hak anak dan perlindungan anak yang bermasalah dengan hukum (Kemenkumham, 2014). Namun Lembaga Pemasyarakatan dengan konsep isolasinya menyebabkan gangguan yang serius secara psikologis, fisik, dan perkembangan bagi narapidana.

Penelitian yang dilakukan oleh The American Academy of Psychiatry mengenai dampak penahanan menunjukkan bahwa tahanan dewasa pada umumnya menunjukkan berbagai reaksi fisiologis dan psikologis seperti halusinasi, kecemasan dan kegelisahan, gangguan emosi, impulsif, kehilangan nafsu makan, penurunan berat badan, jantung berdebar, menarik diri dari lingkungan sosial, mimpi buruk, melukai diri sendiri, depresi berat, trauma hingga bunuh diri. Sedangkan pada narapidana anak dan remaja, toleransi terhadap tekanan jauh lebih rendah dibandingkan dengan orang dewasa sehingga anak-anak juga mengalami efek fisik dan psikis yang sama dengan orang dewasa bahkan lebih buruk lagi. Bunuh diri merupakan dampak yang paling sering ditemui pada narapidana anak. Penelitian tersebut juga menemukan bahwa narapidana anak lebih cenderung melakukan bunuh diri, percobaan bunuh diri, dan terlibat dalam tindakan-tindakan lain yang merugikan diri sendiri (American Civil Liberties Union, 2014).

Berdasarkan data yang diperoleh dari Penelitian Kemasyarakatan (Litmas), diketahui bahwa sebanyak 80\% remaja dengan kasus kriminal mengalami gejala stres saat menjalani proses hukum (Pasudewi, 2012). A Justice Policy Istitute Report juga menemukan bahwa sepertiga dari remaja yang berada di dalam Lembaga Pemasyarakatan mengalami depresi. Munculnya depresi terjadi setelah mereka muai menjalani masa penahanan, sedangkan beberapa remaja yang lain menunjukkan keadaan mental yang buruk hingga bunuh diri (Holman \& Ziedenberg, 2013). Hal ini kemungkinan besar bisa terjadi karena menurut Williams (2007) situasi ketika awal masuk penjara adalah keadaan yang paling mempengaruhi psikologis narapidana. Kegiatan yang bisa dilakukan sesuka hati oleh individu di luar dapat berubah drastis di dalam penjara. Kegiatan yang terjadwal, peraturan, 
peraturan ketat, serta pembatasan waktu untuk bertemu orang yang dicintai adalah peraturan yang harus dijalani di dalam penjara. Belum lagi adanya kelebihan kapasitas dari Lembaga Pemasyarakatan yang dihuni oleh para narapidana.

Permasalahan yang ditemui di dalam Lembaga Pemasyarakatan anak adalah tindakan asusila yang dilakukan oleh narapidana lama terhadap narapidana yang baru masuk Lembaga Pemasyarakatan. Tindakan asusila tersebut dilakukan berkali-kali terhadap narapidana yang sama. Mungkin dikarenakan tidak tahan dengan perlakuan seperti itu, anak yang menjadi korban tindakan asusila tersebut melaporkan kepada petugas. Beberapa minggu setelah kejadian, narapidana tersebut merasa trauma dan seringkali curiga terhadap narapidana lain yang mendekatinya. Setiap malam tidak bisa tidur nyenyak dikarenakan ketakutan apabila terjadi hal seperti itu lagi. Bahkan anak tersebut menjadi pendiam dan enggan berkumpul dengan teman-temannya. Hal ini masih menjadi permasalahan hingga sekarang karena belum adanya psikolog di Lembaga Pemasyarakatan (wawancara, 02/03/2015).

Penganiayaan dan pemukulan antar narapidana anak juga sering terjadi di dalam Lembaga Pemasyarakatan. Pada tahun 2010, terdapat kasus di dalam Lembaga Pemasyarakatan yaitu meninggalnya narapidana yang menjadi korban penganiayaan dan pemukulan oleh narapidana lain. Narapidana yang melakukan penganiayaan tidak hanya memukul, namun juga melukainya dengan menggunakan paku dan juga sendok yang dipipihkan dengan batu. Adanya kasus seperti ini menjadikan narapidana yang lain cemas dan ketakutan, bahkan ada yang mengalami stres dan tidak makan untuk beberapa hari (Wijaya, 2010).

Dalam menjalani kehidupan memang tidak selalu berjalan lancar sesuai rencana yang telah disusun. Secara tidak sadar keberadaan individu di dalam Lembaga Pemasyarakatan merupakan tantangan yang di dalamnya terdapat bermacam permasalahan dan tidak jarang akan berujung pada kegagalan. Kemampuan dalam mengahadapi tantangan berkaitan erat dengan keberhasialan dalam menjalani hidup penuh tekanan. Tingkat kelenturan yang membuat individu mampu untuk bertahan, bangkit, dan menyesuaikan dengan kondisi sekitar inilah yang disebut dengan resiliensi. Resiliensi merupakan kapasitas yang bersifat universal dan dengan kapasitas tersebut individu, kelompok ataupun komunitas mampu mencegah, memini- 
malisir ataupun melawan pengaruh yang bisa merusak saat mereka mengalami musibah atau kemalangan (Grotberg 2003).

Brooks dan Goldstein (2003) mengungkapkan beberapa ciri-ciri individu yang resiilien, yaitu mengetahui caracara membentengi dari dari stres dan mampu mengambil keputusan dan menyelesaikan masalah. Remaja yang pendiam dan enggan berkumpul dengan teman merupakan gambaran bahwa individu tersebut belum mampu menyelesaikan masalah dan belum mengetahui cara membentengi diri dari stres sehingga memilih untuk menarik diri dengan lingkungan sosial. Bonanno (2004) juga mengungkapkan bahwa ciri-ciri orang yang resilien adalah individu yang memiliki kepribadian tangguh, yaitu karakteristik kepribadian individu yang memiliki daya tahan terhadap stres. Dalam hal ini individu mampu mengidentifikasi makna dari peristiwa yang terjadi dalam hidupnya, percaya bahwa dirinya mampu melakukan kontrol dari pengaruh peristiwa yang terjadi, serta mampu memandang perubahan sebagai suatu tantangan, kesempatan, bukan sebaliknya menjadi sebuah ancaman.

Resiliensi memungkinkan anak untuk tetap fokus pada persoalan yang sesungguhnya, dan tidak menyimpang ke dalam perasaan dan pikiran yang negatif, sehingga anak bisa mengatasi resiko depresi dan banyak tantangan. Pikiran dan perasaan adalah inti dalam memahami individu dalam rangka meningkatkan resiliensi (Reivich \& Shatte, 2002). Resiliensi dibutuhkan bagi individu karena resiliensi dapat membangun harga diri (Engel, 2007) sehingga individu yang mempunyai resiliensi yang tinggi, maka harga dirinya juga meningkat. Selain harga diri, resiliensi merupakan faktor protektif serta sumber internal dan eksternal untuk mengatasi stres, memecahkan konflik, dan menguasai seluruh tugastugas perkembangan (Dankonski dkk, 2006). Bagi para narapidana remaja, resiliensi dibutuhkan untuk menghadapi situasi-situasi sulit yang dialami di dalam Lembaga Pemasyarakatan seperti kebosanan, rendahnya harga diri, stres, kekerasan yang dilakukan oleh narapidana lain serta menumbuhkan harapan untuk mampu memperbaiki diri secara positif.

Beberapa penelitian eksperimen yang dilakukan kepada remaja menggunakan intervensi berupa pelatihan dan terapi pada remaja. Pemberian pelatihan dan terapi berfokus pada kemampuan masing-masing individu tanpa melibatkan adanya peran lingkungan dari individu tersebut. Diantaranya adalah penelitian 
yang dilakukan oleh Nisa (2008). Penelitian ini membuktikan bahwa resiliensi pada remaja penyintas gempa dan tsunami dapat ditingkatkan melalui pelatihan manajemen stres. Metode yang digunakan dalam intervensiya adalah metode pelatihan yang diberikan selama 8 kali pertemuan. Penelitian lainnya adalah penelitian yang dilakukan oleh Rembulan (2009) yang menggunakan pelatihan strategi koping fokus emosi pada remaja putri yang tinggal di panti asuhan. Penelitian tersebut terbukti bahwa resiliensi dapat meningkat dengan adanya pelatihan strategi koping fokus emosi.

Selain itu juga Khodayarifard, Shokoohi-Yekta, dan Hamot (2010) melakukan penelitian terkait dengan cognitive-behavioral therapy terhadap narapidana di dalam penjara di Iran. Padahal salah satu faktor yang berperan dalam pengembangan resiliensi adalah social support yang termasuk di dalamnya pengaruh budaya, community support dan personal support. Budaya dan komunitas di mana seseorang itu tinggal sangat mempengaruhi kemampuan resiliensi seseorang. Adanya dukungan dari teman atau lingkungan yang mengalami kejadian serupa termasuk ke dalam salah satu faktor yang mendukung resiliensi. Dukungan dari teman atau peer support adalah jenis dari social support, suatu keadaan di mana seseorang yang memiliki pengalaman yang sama. Fokus dari peer support itu sendiri adalah kelompok pemberi semangat untuk memberikan informasiinformasi, dan membuat nyaman mereka (Rahman, 2009).

Suasana penjara yang tidak ramah dan konsep pemisahan akan menyebabkan anak merasa dirinya pantas mempersalahkan dirinya dan inferioritas. Tidak layak kembali ke masyarakat. Pada akhirnya, ini menciptakan lingkaran residivis karena di lingkungan ini mereka merasa mendapat tempat. Kecenderungan anak melakukan kriminalitas kebanyakan itu justru disebabkan karena kondisi eksternal. Bukan akibat dorongan kesadaran diri secara penuh. Maka, perlu ada pendampingan khusus yang memasukkan nilai-nilai dan pilihanpilihan agar mereka bisa kembali meniti hidup setelah keluar (Harjono, 2009). Pendampingan tersebut salah satunya bisa didapatkan dari dukungan sosial. Wolfelt (2004) menjelaskan bahwa manusia yang sehat memiliki kebutuhan untuk memperoleh dukungan dari temanteman atau orang lain. Dukungan sosial adalah faktor psikososial yang mempengaruhi tingkat resiliensi individu.

Penelitian korelasional yang pernah 
dilakukan oleh Muiz (2011) mengenai hubungan antara peer support dengan resiliensi pada anak di dalam Lembaga Pemasyarakatan Kelas II-A Anak Blitar, menunjukkan bahwa ada hubungan yang positif antara dukungan teman sebaya dengan tingkat resiliensi. Semakin tinggi dukungan teman sebaya maka semakin tinggi pula tingkat resiliensi. Selain itu juga penelitian yang dilakukan oleh Hermaleni (2012) dengan menggunakan terapi dukungan kelompok pada warga binaan wanita kasus narkotika terbukti dapat meningkatkan resiliensi warga binaan wanita kasus narkotika setelah pemberian terapi dukungan kelompok. Penelitian tersebut menunjukkan bahwa terapi dukungan kelompok mampu meningkatkan resiliensi melalui bertukar pengalaman hidup dan saling memberikan dukungan sehingga para warga binaan tidak mengalami kegagalan dalam hidupnya setelah menjalani dan keluar dari lembaga pemasyarakatan.

Adapun hipotesis yang diajukan pada penelitian ini adalah ada pengaruh terapi dukungan kelompok terhadap tingkat resiliensi pada remaja di dalam Lembaga Pemasyarakatan. Kelompok yang mendapatkan terapi dukungan kelompok lebih tinggi tingkat resiliensinya dibandingkan dengan kelompok yang tidak mendapatkan terapi dukungan kelompok. Oleh sebab itu peneliti ingin mengetahui efektivitas terapi dukungan kelompok dalam meningkatkan resiliensi pada remaja di dalam Lembaga Pemasyarakatan.

\section{METODE PENELITIAN}

\section{Desain Penelitian}

Desain penelitian yang digunakan pada penelitian ini adalah kuasi eksperimen. Pemberian pascates dilakukan secara serentak antara kelompok kontrol dan kelompok eksperimen. Partisipan yang diambil adalah partisipan yang memenuhi salah satu atau dua kriteria sekaligus, yaitu masuk dalam kategori sedang, rendah, dan sangat rendah di dalam skala resiliensi. Pada penelitian ini metode eksperimen dilakukan dengan memberikan perlakuan berupa pemberian terapi dukungan kelompok untuk melihat efektivitas perlakuan tersebut terhadap tingkat resiliensi pada remaja di dalam Lembaga Pemasyarakatan.

\section{Subjek Penelitian}

Populasi dalam penelitian ini adalah para narapidana anak yang berada di dalam Lembaga Pemasyarakatan Kelas II-A Anak Blitar dan Lembaga Pemasyarakatan Kleas II-A Anak Kutoarjo. Adapun kriteria subjek penelitian ini adalah 
berjenis kelamin laki-laki dengan rentang usia antara 16-18 tahun, pendidikan terakhir minimal SD, masuk ke dalam Lembaga Pemasyarakatan tahun 2014 dengan lama hukuman minimal 2 tahun, serta memiliki skor resiliensi pada tingkat sangat rendah, rendah, dan sedang.

\section{Metode Pengumpulan Data}

Metode penelitian yang digunakan dalam melakukan pengumpulan data adalah dengan menggunakan observasi, wawancara dan skala resiliensi. Skala yang digunakan merupakan skala yang dimodifikasi dari skala yang pernah ada dan dibuat sendiri oleh peneliti. Skala resiliensi disusun berdasarkan aspekaspek resiliensi yang dikemukakan oleh Connor dan Davidson (2003) yaitu kompetensi personal, standar yang tinggi dan keuletan, percaya pada diri sendiri, memiliki toleransi terhadap afek negatif dan kuat/tegar dalam menghadapi stres, menerima perubahan secara positif dan dapat membuat hubungan yang aman (secure) dengan orang lain, kontrol/ pengendalian diri dalam mencapai tujuan dan bagaimana meminta atau mendapatkan bantuan dari orang lain, serta pengaruh spiritual, yaitu yakin yakin pada Tuhan atau nasib.

Skala resiliensi ini terdiri atas 38 aitem yang terdiri dari 16 aitem favorable dan 16 aitem unfavorable. Setiap pernyataan dalam skala resiliensi ini meminta respon dari subjek dengan memiliki salah satu alternatif jawaban yang telah disediakan. Skala ini disusun berdasarkan skala Likert yang terdiri atas 4 alternatif jawaban, yaitu sangat sesuai (SS), sesuai (S), tidak sesuai (TS) dan sangat tidak sesuai (STS). Hasil uji coba skala resiliensi menunjukkan bahwa dari 38 butir pernyataan, 37 butir dinyatakan sahih dan 1 butir dinyatakan gugur. Butir yang gugur adalah butir nomor 25 . Koefisien korelasi untuk skala yang sahih bergerak antara 0,318 hingga 0,675. Hasil uji coba reliabilitas skala resiliensi menunjukkan bahwa koefisien korelasi sebesar 0,923.

Nilai total diperoleh dari penjumlahan seluruh skor yang diperoleh subjek. Total skor menunjukkan tinggi rendahnya tingkat resiliensi. Semakin tinggi skor yang diperoleh maka semakin tinggi tingkat resiliensi, begitu juga sebaliknya, semakin rendah skor yang diperoleh maka tingkat resiliensi semakin rendah.

\section{Prosedur Penelitian}

Pertama, screening yaitu dengan memberikan skala resiliensi sekaligus sebagai prates, dan dipilih hasil dari skala yang masuk ke dalam kategori sedang, 
rendah, dan sangat rendah untuk dijadikan subjek penelitian. Skala resiliensi yang diberikan telah diuji coba pada tahun 2011 oleh peneliti dengan populasi yang sama. Hasil uji coba menunjukkan 26 aitem gugur dari 64 aitem yang diberikan, sehingga skala resiliensi yang akan dipakai berjumlah 38 aitem.

Kedua, penentuan kelompok kontrol dan kelompok eksperimen, dimana kelompok kontrol dan kelompok eksperimen adalah remaja laki-laki yang berada di Lembaga Pemasyarakatan Klas II-A Anak Blitar.

Ketiga, wawancara untuk menggali permasalahan dan kesanggupan subjek untuk mengikuti proses intervensi yaitu dengan memberikan informed consent. Remaja yang menyatakan bersedia untuk mejadi partisipan dalam penelitian ini akan dijadikan subjek dalam penelitian.

Keempat, pemberian intervensi terapi dukungan kelompok yang dilaksanakan sesuai dengan modul yang telah disusun. Penyusunan modul penelitian adalah hasil modifikasi dari modul yang telah disusun oleh peneliti sebelumnya, yaitu Hermaleni (2012) dan mengacu pada tahapan-tahapan terapi dukungan kelompok dari Heuvel dkk (2002). Terapi ini lebih menekankan pada interaksi yang terjadi antar anggota di dalam kelompok. Kelompok difokuskan kepada anggota untuk saling memberikan umpan balik, memberikan dukungan, berbagi pegalaman dan informasi.

Terapis berperan sebagai pemimpin kelompok sekaligus fasilitator saat proses pelaksanaan kegiatan intervensi. Terapis atau fasilitator yang akan melakukan intervensi dalam penelitian ini harus memiliki kualifikasi sebagai berikut: (1) Psikolog yang memiliki surat izin praktik psikolog; (2) Memiliki pengalaman menjadi terapis kelompok; (3) Memahami dan mampu menggunakan bahasa sehari-hari yang digunakan oleh remaja (bahasa gaul); dan (4) Bersedia terlibat selama proses terapi.

Selain terapis atau fasilitator, intervensi ini juga melibatkan ko-fasilitator yang akan membantu fasilitator selama proses intervensi. Adapun kualifikasi yang harus dimiliki oleh ko-fasilitator adalah sebagai berikut: (1) Mahasiswa magister psikologi profesi bidang klinis dan telah memiliki pengalaman menjalankan praktik kerja profesi sebelumnya; (2) Pernah mengikuti dan menerapkan terapi kelompok.

Kelima, pascates yaitu partisipan kembali diberikan skala resiliensi untuk mengukur tingkat resiliensi setelah intervensi. Skala yang diberikan pada saat pascates sama dengan skala yang diberikan pada saat prates. 
Keenam, tindak lanjut yang dilakukan dua minggu setelah intervensi untuk melihat konsistensi hasil intervensi.

\section{Teknik Analisis Data}

Penelitian ini menggunakan beberapa teknik analisis data. Teknik analisis data Anava campuran digunakan untuk melihat perbedaan antara hasil prates dan pascates juga perbedaan antara hasil prates dan tindak lanjut. Selanjutnya, analisis data ini juga digunakan untuk melihat perbedaan antara kelompok kelompok kontrol dan kelompok eksperimen.

\section{HASIL PENELITIAN}

Jumlah subjek penelitian pada kelompok eksperimen sebanyak 6 remaja yang semuanya berjenis kelamin lakilaki. Subjek yang masuk ke dalam kelompok eksperimen merupakan peserta terapi yang dilakukan selama 4 kali pertemuan. Penelitian ini melakukan pengukuran sebanyak tiga kali, yaitu sebelum intervensi dilakukan (prates), setelah intervensi diberikan (pascates) dan 2 minggu setelah intervensi diberikan (tindak lanjut). Adapun deskripsi data penelitian dapat dilihat pada tabel di bawah ini:

Tabel 1. Deskripsi Data Penelitian Skor Resiliensi

\begin{tabular}{ccccc}
\hline Kelompok & Nama & $\begin{array}{c}\text { Prates } \\
(\mathbf{1})\end{array}$ & $\begin{array}{c}\text { Pascates } \\
\text { (2) }\end{array}$ & $\begin{array}{c}\text { Tindak } \\
\text { Lanjut } \\
\text { (3) }\end{array}$ \\
\hline \multirow{6}{*}{ Eksperimen } & MU & 97 & 101 & 105 \\
& YU & 102 & 105 & 106 \\
& $\mathrm{AG}$ & 74 & 105 & 111 \\
& $\mathrm{BU}$ & 91 & 92 & 94 \\
& $\mathrm{TI}$ & 103 & 116 & 116 \\
& $\mathrm{HA}$ & 103 & 107 & 107 \\
\hline \multirow{6}{*}{ Kontrol } & $\mathrm{PU}$ & 98 & 97 & 98 \\
& $\mathrm{FR}$ & 99 & 97 & 97 \\
& $\mathrm{MO}$ & 82 & 84 & 83 \\
& $\mathrm{R}$ & 91 & 87 & 88 \\
& $\mathrm{RO}$ & 101 & 100 & 100 \\
& $\mathrm{RA}$ & 104 & 104 & 102 \\
\hline
\end{tabular}

Pascates dalam tabel di atas men mengalami peningkatan skor resimenunjukkan semua kelompok eksperi- liensi setelah diberikan intervensi berupa 
terapi dukungan kelompok. Sedangkan pada kelompok kontrol terdapat 1 subjek yang mengalami peningkatan skor, 1 subjek yang mendapatkan skor tetap, dan 4 subjek yang mengalami penurunan skor.

Tabel 2. Deskripsi Data Statistik

\begin{tabular}{clrrc}
\hline & Kelompok & \multicolumn{1}{c}{ Mean } & Std. Deviation & $\mathbf{N}$ \\
\hline \multirow{3}{*}{ Prates } & Eksperimen & 95.00 & 11.296 & 6 \\
& Kontrol & 95.83 & 8.035 & 6 \\
& Total & 95.42 & 9.356 & 12 \\
\hline \multirow{3}{*}{ Pascates } & Eksperimen & 104.33 & 7.840 & 6 \\
& Kontrol & 94.83 & 7.731 & 6 \\
& Total & 99.58 & 8.929 & 12 \\
\hline \multirow{2}{*}{ Tindak } & Eksperimen & 106.50 & 7.342 & 6 \\
Lanjut & Kontrol & 94.67 & 7.474 & 6 \\
& Total & 100.68 & 9.385 & 12 \\
\hline
\end{tabular}

Berdasarkan tabel di atas terlihat bahwa Mean pada pascates di kelompok eksperimen sebesar 104.33 dan kelompok kontrol sebesar 94.83, skor ini menunjukkan bahwa rata-rata skor pascates resiliensi pada kelompok eksperimen lebih tinggi dibandingkan dengan rata-rata skor pada kelompok. Hal ini juga dialami pada saat tindak lajut, rata-rata skor pada kelompok eksperimen (106.50) lebih tinggi dibadingkan dengan rata-rata skor pada kelompok kontrol (94.67).

Hasil uji normalitas dari skala resiliensi diperoleh nilai $\mathrm{K}$-SZ $=0.810$ dan nilai $p=0.528(p>0.05)$. kaidah uji normalitas yang digunakan adalah apabila $p>0.05$ maka sebaran data tersebut normal namun apabila $p<0.05$ maka sebaran data tersebut tidak normal. Berdasarkan hasil uji normalitas maka didapatkan bahwa sebaran data tersebut normal.

Hasil uji homogenitas dari skala resiliensi ini memperoleh nilai levene statistic $=0.429$ dan nilai $\mathrm{p}=0.527$ $(p>0.05)$. Berdasarkan hasil uji homogenitas maka didapatkan bahwa kedua kelompok termasuk homogen. 
Tabel 3. Data Perbandingan Hasil Uji Hipotesis Resiliensi

\begin{tabular}{|c|c|c|c|c|c|c|c|}
\hline \multirow{2}{*}{ Group } & \multicolumn{2}{|c|}{ Time } & \multirow{2}{*}{$\begin{array}{c}\text { Mean } \\
\text { Difference } \\
(\mathrm{I}-\mathrm{J})\end{array}$} & \multirow{2}{*}{$\begin{array}{l}\text { Std. } \\
\text { Error }\end{array}$} & \multirow{2}{*}{ Sig. ${ }^{a}$} & \multicolumn{2}{|c|}{$\begin{array}{l}95 \% \text { Confidence } \\
\text { Interval for } \\
\text { Difference }\end{array}$} \\
\hline & (I) & (J) & & & & $\begin{array}{l}\text { Lower } \\
\text { Bound }\end{array}$ & $\begin{array}{l}\text { Upper } \\
\text { Bound }\end{array}$ \\
\hline \multirow[b]{2}{*}{ Eksperimen } & Prates & $\begin{array}{l}\text { Pasca- } \\
\text { tes }\end{array}$ & -9.333 & 3.340 & 0.019 & -16.775 & -1.891 \\
\hline & Prates & $\begin{array}{l}\text { Tindak } \\
\text { Lanjut }\end{array}$ & -11.500 & 3.787 & 0.013 & -19.937 & -3.063 \\
\hline \multirow[b]{2}{*}{ Kontrol } & Prates & $\begin{array}{l}\text { Pasca- } \\
\text { tes }\end{array}$ & 1.000 & 3.340 & 0.771 & -6.442 & 8.442 \\
\hline & Prates & $\begin{array}{l}\text { Tindak } \\
\text { Lanjut }\end{array}$ & 1.167 & 3.787 & 0.764 & -7.271 & 9.604 \\
\hline
\end{tabular}

Hasill uji hipotesis dari sebelum pelaksanaan intervensi hingga setelah pelaksanaan intervensi menunjukkan adanya perubahan yang mengarah pada peningkatan resiliensi. Hal ini dapat dilihat dari perolehan skor Mean Difference prates-pascates $=-9,333$ dengan nilai signifikansi $p=0,019(p<0,05)$, artinya bahwa aspek resiliensi menunjukkan adanya perubahan yang signifikan. Kemudian pengukuran resiliensi dilakukan kembali untuk mengetahui dampak intervensi setelah masa tenggang waktu sebagai tahapan tindak lanjut, guna mengetahui konsistensi tingkat resiliensi peserta terapi. Hasilnya dapat dilihat bahwa skor resiliensi dari sebelum intervensi hingga tindak lanjut menunjukkan perubahan dengan nilai Mean
Differences prates tindak lanjut $=$ 11,500 dengan nilai signifikansi $p=$ $0,013(p<0,05)$.

Hasil uji hipotesis pada kelompok kontrol ketika prates-pascates mendapatkan nilai $p=0,771(p>0,05)$ dan ketika prates-tindak lanjut mendapatkan nilai $p$ $=0,764(p>0,05)$. Hal ini menunjukkan bahwa tidak terdapat perbedaan yang signifikan antara skor prates dengan pascates pada kelompok kontrol, dan juga tidak terdapat perbedaan yang signifikan antara skor prates dengan tindak lanjut pada kelompok kontrol. Berdasarkan hasil uji hipotesis di atas, maka dapat disimpulkan bahwa terapi dukungan kelompok terbukti secara signifikan dapat meningkatkan resiliensi pada remaja di dalam Lembaga 
Pemasyarakatan Anak Kelas II-A Blitar.

\section{PEMBAHASAN}

Penelitian ini bertujuan untuk mengetahui efektivitas terapi dukungan kelompok dalam meningkatkan resiliensi pada remaja di dalam Lembaga Pemasyarakatan. Berdasarkan analisis data yang telah dilakukan didapatkan hasil bahwa terdapat perbedaan tingkat resiliensi antara kelompok eksperimen yang diberikan intervensi dengan kelompok kontrol yang tidak diberikan intervensi. Menurut hasil data kuantitatif, antara kelompok eksperimen dan kelompok kontrol mengalami perubahan skor resiliensi pada saat prates dan pascates juga ketika tindak lanjut, akan tetapi perubahan skor yang terjadi pada kelompok eksperimen mengalami peningkatan sedangkan pada kelompok kontrol mengalami peningkatan dan penurunan. Berdasarkan angka juga didapatkan hasil yang lebih besar peningkatannya pada kelompok eksperimen dibandingkan dengan kelompok kontrol. Hal ini menunjukkan bahwa terapi dukungan kelompok sebagai intervensi secara efektif mampu meningkatkan resiliensi remaja di dalam Lembaga Pemasyarakatan Anak.
Terapi dukungan kelompok disusun sebagai bentuk intervensi bagi para narapidana yang di dalamnya terdapat proses saling berbagi informasi, penggalian masalah, pengungkapan ide dan perasaan, saling berbagi pengalaman dan pembelajaran pemecahan masalah dari peserta dan fasilitator/terapis. Norma kelompok juga disepakati pada awal pertemuan untuk membangun sikap saling percaya antar anggota kelompok sehingga mereka saling terbuka terhadap masalahnya (Prawitasari, 2011).

Terapi dukungan kelompok ini memiliki beberapa kelebihan yang medukung keberhasilan terapi diantaranya yaitu adanya kelompok dapat memberikan kesempatan pada anggota untuk saling memberi dan menerima umpan balik, dengan cara ini kelompok akan belajar mengenai informasi dan perilaku yang baru. Selain itu juga terapi dukungan kelompok dapat menjadi sarana untuk berbagi pengalaman serta menuangkan ide dan perasaan anggota kelompok sehingga anggota kelompok yang lain dapat memberikan pendapat yang akan mengubah sikap dan perilaku anggota kelompok lainnya.

Dukungan dari sesama anggota menjadi sangat penting dalam sebuah keberhasilan terapi ini. Melalui dukungan antar sesama, anggota kelompok akan 
merasa diterima dan mendapatkan perhatian dari orang lain sekaligus belajar untuk melatih keterampilan sosial karena meurut Heuvel, dkk (2002) partisipan intervensi juga dapat belajar untuk membuat suasana positif bagi orang lain. Cara-cara ini akan meningkatkan hubungan antar pribadi yang efektif. Hubungan yang efektif menjadikan antar anggota kelompok memiliki kepercayaan dan kenyamanan untuk berbagi informasi dan pengalaman serta memberikan umpan balik kepada anggota lainnya.

Hasil penelitian menyatakan terdapat peningkatan resiliensi narapidana remaja setelah mengikuti terapi dukungan kelompok. Hasil penelitian ini sama dengan hasil penelitian sebelumnya yang menguji efektivitas terapi dukungan kelompok dalam mengembangkan daya resiliensi remaja (Djudiyah, 2010). Selain itu juga terdapat penelitian lain yang memiliki hasil penelitian yang sama dengan peneliti, yaitu penelitian yang menguji efektivitas terapi dukungan kelompok dalam meningkatkan resiliensi warga binaan wanita kasus narkotika (Hermaleni, 2012).

Greeff dan Wentworth (2009) menyebutkan salah satu faktor yang mempengaruhi resiliensi adalah dukungan sosial. Pada terapi dukungan kelompok ini individu dapat mengakses dukungan sosial yang positif. Narapidana remaja yang mengalami peningkatan resiliensi setelah mengikuti terapi dukungan kelompok disebabkan oleh adanya dukungan sosial dan interaksi positif yang tercipta antar sesama subjek penelitian. Peningkatan ini dapat dilihat dari faktor resiliensi yang berupa menerima perubahan secara positif dan dapat membuat hubungan yang aman (secure) dengan orang lain. Semua subjek mampu menunjukkan dirinya bahwa ia dapat dipercaya oleh orang lain sehingga subjek yang lainnya mampu secara aktif menceritakan pengalaman-pengalaman mereka baik pengalaman positif maupun negatif, bahkan salah satu subjek yang sebelumnya tidak pernah menceritakan permasalahannya kepada orang lain dapat mengungkapkan pengalamannya di dalam kelompok terapi.

Terapi dukungan kelompok yang telah dilaksanakan mampu memberikan fungsi terapeutiknya terhadap kelompok, yaitu sebagai faktor dukungan (supportive factors), faktor keterbukaan diri dan katarsis, faktor belajar kebijaksanaan atau kearifan dari anggota kelompok lainnya, serta faktor-faktor psikologis yang berkaitan dengan bagaimana menjalin hubungan dengan orang lain dan bagaimana memahami diri sendiri (Brabender, Fallon, \& Smolar, 2004). 
Faktor dukungan (supportive factors) adalah salah satu yang paling penting dalam terapi dukungan kelompok. Setiap anggota yang masuk dalam kelompok selalu dalam kondisi yang tidak menyenangkan dan dalam keadaan tidak nyaman mengenai situasi yang mereka hadapi. Faktor-faktor dukungan berhubungan dengan memacu harapan, penerimaan, tolong menolong, kebersamaan, dan senasib sepenanggungan. Dukungan dan penerimaan dari anggota kelompok yang lain dapat menciptakan harapan terhadap semua subjek untuk menciptakan dan mencapai tujuan yang akan dihadapinya kemudian hari. Pertemuan terakhir intervensi memberikan kesempatan kepada masing-masing subjek untuk mengungkapkan tujuan hidupnya kelak ketika keluar dari Lapas.

Selanjutnya, perlu dilakukan evaluasi mengenai proses penelitian telah dilakukan terhadap fasilitator dan observer, alat ukur, pelaksanaan terapi, dan pembagian kelompok.

Fasilitator dinilai baik dalam memegang jalannya terapi kelompok. Selain itu melaksanakan norma kelompok dengan baik sehingga peserta merasa nyaman. Fasilitator juga menyampaikan informasi dan instruksi secara jelas sesuai dengan bahasa yang dipahami oleh remaja. Selain evaluasi terhadap fasili- tator, observer juga menjadi bagian dalam proses penelitian sehingga perlu dilakukan evaluasi. Observer dinilai melakukan tugasnya dengan baik dan melakukan pengamatan serta pencatatan dengan teliti.

Alat ukur yang digunakan merupakan skala resiliensi yang disusun berdasarkan aspek-aspek resiliensi. Skala tersebut pernah diujicobakan kepada populasi yang sama pada tahun 2011 dan diuji coba kembali pada populasi serupa an di tempat yang sama pada penelitian ini. Hal ini menjadikan alat ukur yang dipakai lebih sesuai dan spesifik khusus untuk subjek penelitian dalam penelitian ini. Modul intervensi diterapkan secara runtut sesuai dengan rancangan pelaksanaan meskipun terdapat modifikasi seperti diberikannyaa ice breaking ketika jeda antar sesi pada setiap pertemuan yang sebelumnya tidak dituliskan dalam rancangan intervensi.

Pelaksanaan terapi yang dilakukan di ruang sidang dirasa kurang nyaman karena adanya petugas Lapas yang ikut masuk ke dalam ruangan karena kontak langsung dengan narapidana harus didampingi oleh petugas. Adanya petugas yang berada di dalam ruangan terapi menyebabkan peserta kurang kooperatif dalam menceritakan pengalamannya. Pada pertemuan kedua, ketiga dan 
keempat petugas yang mengawasi memutuskan untuk duduk di depan pintu ruangan setelah fasilitator menjelaskan kepada petugas tentang ketidaknyamanan subjek.

Pembagian kelompok eksperimen dan kelompok kontrol pada awalnya didapatkan dari tempat Lapas yang berbeda, yaitu Lembaga Pemasyarakatan Anak Kelas II-A Blitar sebagai kelompok eksperimen dan Lembaga Pemasyarakatan Anak Kelas II-A Kutoarjo sebagai kelompok kontrol. Pada pelaksanaanya, antara kelompok eksperimen dan kelompok kontrol terdiri dari remaja yang berada di dalam Lembaga Pemasyarakatan Anak Kelas II-A Blitar. Hal ini disebabkan karena peneliti belum mendapatkan ijin untuk melakukan penelitian dari Lembaga Pemasyarakatan Anak Kelas II-A Kutoarjo dan pada saat yang bersamaan Lembaga Pemasyarakat-an Anak Kelas IIA Blitar sudah memberikan ijin melakukan penelitian. Lapas Anak Kutoarjo baru memberikan ijin pada akhir bulan Agustus dikarenakan pada bulan Mei hingga Agustus banyak mahasiswa yang sedang melakukan penelitian di Lapas tersebut.

\section{SIMPULAN DAN SARAN}

\section{Simpulan}

Hasil penelitian menunjukkan bahwa terapi dukungan kelompok secara efektif dapat meningkatkan resiliensi pada remaja di dalam Lembaga Pemasyarakatan. Kelompok yang mendapatkan intervensi terapi dukungan kelompok lebih tinggi tingkat resiliensinya dibandingkan dengan kelompok yang tidak mendapatkan terapi dukungan kelompok.

\section{Saran}

Untuk penelitian selanjutnya perlu ditindaklanjuti dengan sejumlah saran: (1) Menggunakan kelompok eksperimen dan kelompok kontrol pada tempat yang berbeda agar validitas internal penelitian semakin baik; (2) Penelitian ini bisa menjadi acuan dalam mengembangkan terapi kelompok pada bentuk yang berbeda; (3) Minimnya penelitian eksperimen pada Lembaga pemasyarakatan Anak bisa menjadi bahan pertimbangan bagi penelitian selanjutnya untuk mengembangkan dan menambah referensi baru sebagai upaya pendampingan dan pembinaan pada narapidana remaja.

Untuk subjek penelitian: (1) Subjek penelitian diharapkan dapat menerapkan pengetahuan, informasi, ide dan saran 
dari subjek yang lainnya dalam kehidupan sehari-hari; (2) Menciptakan hubungan pertemanan yang efektif akan meningkatkan kesehatan mental masingmasing subjek sehingga perasaan bosan, sedih, putus asa, setres bahkan depresi bisa teratasi melalui bercerita, saling mendukung, saling menerima, berbagi pengalaman dan bercanda.

Untuk lembaga pemasyarakatan anak kelas II-A Blitar: (1) Hasil penelitian ini dapat digunakan sebagai acuan dalam pengembangan program pembinaan berbasis kelompok di dalam Lembaga Pemasyarakatan Anak sebagai salah satu usaha untuk meningkatkan kesehatan mental narapidana; (2) Menempatkan psikolog di dalam lapas agar fungsi Lembaga Pemasyarakatan sebagai tempat pembinaan belum berjalan secara maksimal.

\section{DAFTAR PUSTAKA}

American Civil Liberties Union. (2014). Alone and Afraid: Children Held in Solitary Confinement and Isolation in Juvenile Detention and Correctional Facilities. New York: ACLU

Bonanno, G. A. (2004). Loss, Trauma and Human Resilience: Have We Underestimated the Human Capacity to Thrive after Extremely
Aversive Events. American Psychlogist Association. 59(1), 2028

Brabender, V. A., Fallon, A. E., \& Smolar, A. I. (2004). Essensials of Group Therapy. New Jersey: Wiley \& Sons, Inc.

Brooks, R., \& Goldstein, S. (2003). The Power of Resilience. United Stated: Mac Graw-Hill

Connor \& Davidson. (2003). Development of a New Resilience Scale: The Connor-Davidson Resilience Scale (CD-RISC). Journal of Depression and Anxiety, Vol 18, 76-82

Dankonski, M. E., Keiley, M. K., Thomas, V., Chice, P., Lloyd, S. A., \& Seery B. L. (2006). Affect Regulation and Cycle of Violence Again Women: New Direction for Understanding the Process. J Fam Vol. 21, 327339

Djudiyah \& Yuniardi, S. M. (2010). Model Pengembangan Konsep Diri dan Daya Resiliensi Melalui Support Group Therapy: Upaya Meminimalkan Trauma Psikis Remaja dari Keluarga Single Parent. Malang: Universitas Muhammadiyah Malang (tesis tidak diterbitkan)

Engel, B. (2007). Eagle Soaring; the 
Power of the Resilient Self. Journal of Psychological Nursing. 45(2), 44-49

Greeff, A. P., \& Wentworth, A. (2009). Resilience in Families that Have Experienced Heart-Related Trauma. Current Psychology. 28, 302-304

Grotberg, E. H. (2003). Resilience for Today; Gaining Strength from Adversity. USA: Greenwood Publishing Group, Inc.

Harjono, Y. (2009). Jadikan Penjara Anak Seperti Asrama. Bandung: Kompas

Hermaleni, T. (2012). Efektivitas Support Group Therapy dalam Meningkatkan Resiliensi Warga Binaan Wanita Kasus Narkotika. Yogyakarta: Universitas Gajah Mada (Thesis tidak diterbitkan)

Heuvel, E., Witte, L., Stewart, R., Schure, L., Sanderman, R., \& Jong, B. (2002). Long-Term Effect of a Group Support Program and an Individual Support Program for Informal Caregivers of Stroke Patients : Which Caregivers Benefit the Most?. Patient Education and Counseling, 47, 291-299

Holman, B., \& Ziedenberg, J. (2013). The Dangers of Detention; The Impact of Incarcerating Youth in Detention and Other Secure Facilities. A
Justice Policy Institute Report.

Kemenkumham. (2014). Lapas Anak Klas IIA Blitar. www.jatim. kemenkumham.go.id/satuankerja/upt/pemasyarakatan/lembagapemasyarakatan-lapas/lapas-anakklas-iia-blitar (diakses tanggal 07/05/2015)

Khodayarifard, M., Shokoohi-Yekta, M., \& Hamot, G. E. (2010). Effects of Individual and Group CognitiveBehavioral Therapy for Male Prisoners in Iran. International Joural of Offender Therapy and Comparative Criminology, 54(5), 743-755

Muiz, R. H. (2011). Hubungan antara Peer Support dengan Resiliensi pada Anak di dalam Lembaga Pemasyarakatan. Universitas Islam Indonesia (skripsi tidak diterbitkan)

Nisa, H. (2008). Pelatihan Manajemen Stres untuk Meningkatkan Resiliensi Remaja Penyintas Gempa dan Tsunami di Nanggroe Aceh Darussalam. Universitas Gadjah Mada (thesis tidak diterbitkan)

Pasudewi, C. Y. (2012). Resiliensi pada Remaja Binaan Bapas Ditinjau dari

Coping Stress. Journal of Social and Industrial Psychology, 1 (2), 14-21 
Prawitasari, J. E. (2011). Psikologi Klinis Pengantar Terapan Mikro dan Makro. Jakarta: Penerbit Erlangga

Rahman, B. (2009). Peer Support and Resilience. Down Syndrome Victoria Members Journal. Voice, Winter, 4-5

Reivich, K \& Shatte, A. (2002). The Resilience Factor; Seven Essential Skill for Overcoming Live's Inevitable Obstacle. New York: Random House

Rembulan, C. L. (2009). Penguatan Resiliensi dengan Pelatihan Strategi Koping Fokus Emosi pada Remaja Putri yang Tinggal di Panti Asuhan. Tesis. Yogyakarta: Universitas Gadjah Mada.
Wijaya, Y. (2010). Tahanan Anak Dibunuh di Palembang, Alat Kelaminnya Dipotong. http://hileud.com/hileudnews?title $=$ Tahanan + Anak + Dibunuh + di + Palembang $\% 2 C+$ Alat + Kela minnya + Dipotong\&id $=43762$ (diakses tanggal 25/02/2015)

Williams, N. H. (2007). Prison Health and the Health of the Public; Ties that Bind. Community Voice Healthcare for the Underserved. Atlanta: National Center for Primary Care

Wolfert, A. D. (2004). The Understanding Your Grief Support Group Guide: Starting and Leading a Bereavement Support Group. USA: Companion Press 